Digitized by the Internet Archive in 2018 with funding from

The Arcadia Fund 


\section{Amphibians of Central and Southern Africa}


COMSTOCK BOOKS IN HERPETOLOGY Aaron M. Bauer, Consulting Editor 


\section{Amphibians of Central and Southern Africa}

Alan Channing

Comstock Publishing Associates

a division of

CORNELL UNIVERSITY PRESS

ITHACA AND LONDON 
Copyright @ 2001 by Cornell University

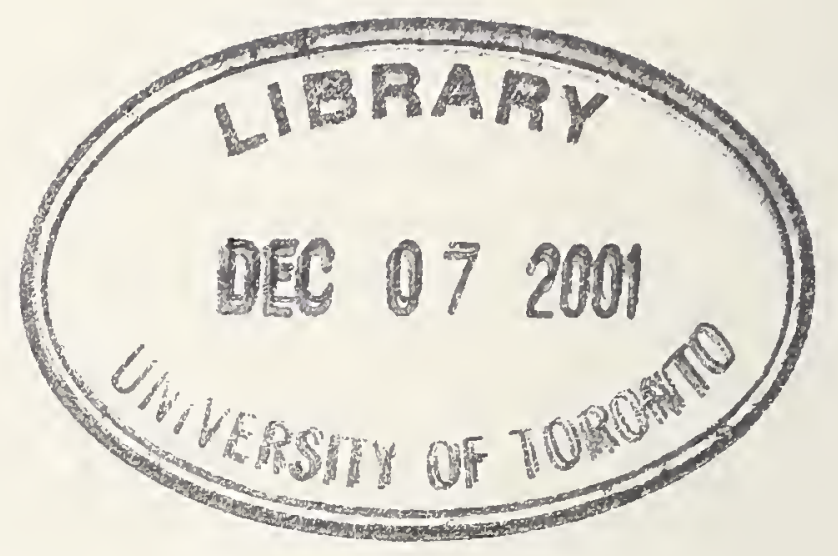

All rights reserved. Except for brief quotations in a review, this book, or parts thereof, must not be reproduced in any form without permission in writing from the publisher. For information, address Cornell University Press, Sage House, 512 East State Street, Ithaca, New York 14850.

First published 2001 by Cornell University Press

Printed in the United States of America

Library of Congress Cataloging-in-Publication Data

Channing, A.

Amphibians of Central and Southern Africa / Alan E. Channing. p. $\mathrm{cm}$.

Includes bibliographical references (p. ).

ISBN 0-8014-3865-9 (cloth)

1. Amphibians-Africa, Southern. I. Title.

QL662.A356 C43 2001

$597.8^{\prime} 0968-\mathrm{dc} 21$

2001037091

Cornell University Press strives to use environmentally responsible suppliers and materials to the fullest extent possible in the publishing of its books. Such materials include vegetable-based, low-VOC inks and acid-free papers that are recycled, totally chlorine-free, or partly composed of nonwood fibers. For further information, visit our website at www.cornellpress.cornell.edu.

Cloth printing 10987654321 